\title{
Penerapan Metode Weighted Product Untuk Sistem Pendukung Keputusan Penerima Beasiswa Politeknik Harapan Bersama Tegal
}

\author{
Dyah Apriliani* $^{* 1}$, Slamet Wiyono ${ }^{2}$, Septian Mahardhika ${ }^{3}$ \\ 1,2,3 Jurusan Teknik Informatika, Politeknik Harapan Bersama, Tegal \\ 1,2,3 Jln. Mataram No.09, Margadana, Tegal, 50272, Indonesia \\ email: ${ }^{1}$ dyah.apriliani90@gmail.com, ${ }^{2}$ slamet2wiyono@gmail.com, ${ }^{3}$ septianmahardhika@ gmail.com
}

Received: 31 Maret 2018; Revised:12 Mei 2018; Accepted: 13 Mei 2018

Copyright $\odot 2018$ Politeknik Harapan Bersama Tegal. All rights reserved

\begin{abstract}
The scholarship is an educational aid that given to the student in a university. Scholarship are usually given to students, neither economically underprivileged students nor students who have great achievement in an academic field or non-academic field. Politeknik Harapan Bersama as one of education provider in higher education gives scholarships to their students. Scholarship that given to underprivileged students known as Student Learning Aid scholarship (BBM) and scholarships are given to students with academic achievement know as Potential Academic Improvement Scholarship (PPA). The aim of this research is to build decision support system of scholarship recipient using Weighted Product (WP) method. Decisionmaking system of scholarship receiver is still done by manual, so it takes long time in deciding scholarship receiver. The scholarship grantee decision support system using the Weight Product method is expected to select scholarship receiver automatically when the value for each criterion has been inputted in the system, so resulting in a ranking which calculated using Weight Product method. With this system, the decision making is more objective. The result of this system is the ranking of scholarship receiver candidate.
\end{abstract}

Abstrak - Beasiswa merupakan bantuan pendidikan yang diberikan kepada mahasiswa dalam sebuah perguruan tinggi. Beasiswa biasanya diberikan untuk mahasiswa, baik mahasiswa yang kurang mampu dari sisi ekonominya maupun mahasiswa yang memiliki prestasi dalam bidang akademik maupun non akademik. Politeknik Harapan Bersama sebagai salah satu penyelenggara pendidikan di tingkat Perguruan Tinggi memberikan beasiswa kepada mahasiswanya. Beasiswa yang diberikan berupa beasiswa bagi mahasiswa yang kurang mampu yang biasa dikenal dengan nama Beasiswa Bantuan Belajar Mahasiswa (BBM) dan beasiswa yang diberikan kepada mahasiswa yang memiliki prestasi yang dikenal dengan nama beasiswa Peningkatan Potensi Akademik (PPA). Penelitian yang dilakukan ini bertujuan untuk membangun sebuah sistem pendukung keputusan penerima beasiswa dengan menggunakan metode Weighted Product (WP). Sistem Pengambilan keputusan penerima beasiswa saat ini masih dilakukan dengan cara manual, sehingga membutuhkan waktu yang lama dalam memutuskan penerima beasiswa. Sistem pendukung keputusan penerima beasiswa menggunakan metode Weighted Product ini

*) Corresponding author: Dyah Apriliani

Email: dyah.apriliani90@gmail.com diharapkan mampu menyeleksi penerima beasiswa secara otomatis ketika nilai untuk masing-masing kriteria sudah diinputkan di sistem, sehingga menghasilkan perangkingan yang dihitung menggunakan metode Weight Product. Dengan adanya sistem ini maka pengambilan keputusan yang dilakukan lebih bersifat objektif. Hasil dari sistem ini adalah perangkingan calon penerima beasiswa.

Kata Kunci - Sistem Pendukung keputusan, Weighted Procduct, Beasiswa.

\section{PENDAHULUAN}

Politeknik Harapan Bersama merupakan perguruan tinggi vokasi yang mencetak mahasiswanya sebagai sumber daya manusia untuk menjadi praktisi di lingkunagn industri maupun perusahaan. Untuk menunjang proses pembelajaran di lingkungan Politeknik Harapan Bersama menyediakan beberapa sarana dan prasarana serta fasilitas penunjang lainnya diantaranya: perpustakaan, rumah susun mahasiwa, ruang kelas yang memadai, laboratorium, hotspot area dan sistem informasi. Tidak hanya dalam bidang sarana dan prasarana, Politeknik Harapan Bersama juga memberikan fasilitas bagi mahasiswanya, baik itu mahasiswa yang memiliki prestasi akademik maupun non-akademik serta mahasiswa yang kurang mampu. Beasiswa mahasiswa merupakan bantuan pendidikan yang diberikan tidak hanya untuk mahasiswa yang memiliki orang tua kurang mampu, tetapi juga untuk mahasiswa yang memiliki prestasi. Politeknik Harapan memberikan beasiswa kepada mahasiswa berupa beasiswa Peningkatan Prestasi Akademik (PPA) dan beasiswa Bantuan Belajar Mahasiswa (BBM). Politeknik Harapan bersama memiliki kriteria tersendiri dalam menentukan penerima beasiswa. Kriteria yang digunakan diantaranya IPK, jumlah SKS yang telah diambil, keikutsertaan dalam kegiatan kemahasiswaan dan tingkat kemampuan ekonomi. [1]

Seiring perkembangan teknologi, sistem pendukung keputusan juga banyak digunakan dalam berbagai bidang, misalnya bidang perbankan, pendidikan, pertanian dan bidang lainnya [2]. Sistem pendukung keputusan digunakan dalam dunia perbankan untuk penentuan lokasi pembukaan cabang baru sebuah Bank [3]. Sistem pendukung keputusan 
juga dapat diimplementasikan dalam dunia pendidikan, salah satunya dapat digunakan untuk melakukan seleksi penerimaan beasiswa. Seleksi penerima beasiswa mahasiswa di Politeknik Harapan Bersama saat ini masih dilakukan secara manual sehingga mengalami kesulitan dalam menentukan siapa yang menerima beasiswa mengingat banyaknya calon penerima beasiswa dan juga banyaknya kriteria penilaian yang digunakan. Selain itu proses seleksi ini juga membutuhkan waktu yang cukup lama. Dengan adanya fasilitas yang sudah memadai, sudah seharusnya Politeknik Harapan Bersama saat ini memiliki sebuah sistem pendukung keputusan yang mampu mengelola pendaftaran beasiswa, proses penilaian sampai dengan pengumuman beasiswa. Pembuatan sistem pendukung keputusan ini diharapkan mampu mempercepat dan mempermudah proses pengambilan keputusan penerimaan beasiswa di Politeknik Harapan Bersama.

Sistem Pendukung Keputusan yang dibuat untuk menentukan calon penerima beasiswa baik beasiswa PPA maumun Beasiswa BBM tentunya membutuhkan algoritma dalam sistem pendukung keputusan. Salah satu dari algoritma tersebut adalah Fuzzy Multiple Attribute Decision Making (Fuzzy-MADM). Fuzzy MADM digunakan dalam pemberian penilaian maupun proses seleksi untuk menentukan alternative terbaik dari sejumlah alternative yang ada [4]. Salah satu metode yang ada dalam algoritma Fuzzy-MADM yaitu metode Weighted Product atau yang biasa dikenal dengan istilah WP [5]. Metode Weighted Product (WP) merupakan metode yang dalam proses penyelesaian dan perhitungannya menggunakan perkalian untuk menghubungkan rating dari atributnya, rating dari masingmasing atribut selanjutnya dipangkatkan dengan bobot dari atribut yang bersangkutan. Tahap perankingan dilakukan dengan memberikan penilaian dan pembobotan pada masingmasing kriteria disetiap alternatif. Hasil perankingan ini yang nantinya akan digunakan sebagai dasar penentuan pemberian beasiswa. Metode Weighted Product ini digunakan dalam penelitian ini dikarenakan metode ini dapat melakukan proses seleksi dengan baik sehingga menghasilkan alternatif terbaik dari sejumlah alternatif yang diberikan, selain itu proses pembobotan dalam metode Weighted Product ini dapat diatur dan disesuaikan dengan kebutuhan pengambil keputusannya sehingga lebih fleksibel dan hasil perhitungan yang dihasilkan sesuai dengan kebutuhan pengambil keputusannya [6]. Metode Weighted Product mampu menyelesaikan masalah dengan banyak kriteria di dalamnya [7]. Metode Weighted Product ini juga menghasilkan perhitungan yang lebih menyeluruh dibandingkan dengan metode lain di dalam algoritma Fuzzy MADM [8]. Alternatif yang digunakan dalam penelitian ini adalah pendaftar beasiswa yang ada di lingkungan Politeknik Harapan Bersama.

Tujuan dilakukannya penelitian ini yaitu mampu membangun sistem pendukung keputusan penerima beasiswa dengan menggunakan metode Weighted Product sehingga dapat membantu proses penyeleksian calon penerima beasiswa baik Beasiswa-PPA maupun Beasiswa-BBM di lingkungan Politeknik Harapan Bersama Tegal. Dengan mengimplementasikan metode Weight Product ini mampu meghasilkan output yang lebih akurat dan objektif.

\section{PENELITIAN YANG TERKAIT}

Penelitian yang telah dilakukan yang terkait dengan penelitian ini diantaranya, penelitian tentang rancang bangun aplikasi sistem pendukung keputusan penerimaan beasiswa dengan menggunakan metode SAW. Dalam sistem ini digunakan beberapa kriteria penilaian diantaranya IPK mahasiswa, penghasilan orang tua, prestasi, keaktifan dan jumlah tanggungan orang tua. Penelitian yang dilakukan menghasilkan suatu sistem pendukung keputusan yang mampu mengakomodasi penerimaan beasiswa. Aplikasi ini dibangun menggunakan program aplikasi lazarus [4].

Penelitian lain terkait dengan sistem pendukung keputusan kelayakan penerimaan bantuan beras dengan menggunakan weighted product di Kelurahan Krikil, Kecamatan Mangkubumi Kota Tasikmalaya. Sistem dikembangkan untuk membantu dan mempermudah proses pengambilan keputusan dalam menentukan warga yang berhak menerima bantuan beras. Penelitian dilakukan dengan menggunakan metode Wieghted Product (WP) [9]. Metode Weight Product banyak digunakan dalam penelitian tentang Sistem Pendukung Keputusan. Penelitian lain dengan menggunakan metode weight product dapat dilihat dalam penelitian dengan judul Implementasi Weighted Product (WP) dalam Penentuan penerimaan bantuan langsung masyarakat mandiri [10].

Penelitian mengenai pemanfaatan metode Weighted Product dalam sistem pendukung keputusan penerimaan beasiswa prestasi untuk siswa, menyebutkan bahwa metode ini mampu menyeleksi alternatif yang baik dengan keunggulan di teknik pembobotan. Kriteria yang digunakan dalam penilaian ini adalah nilai, kehadiran, penghasilan orang tua, dan jumlah tanggungan orang tua. Penelitian ini menghasilkan sistem yang mampu mempercepat proses penerimaan beasiswa [11]

Penelitian ini berbeda dengan penelitian yang penulis lakukan, perbedaannya dapat dilihat dari kritera yang digunakan, nilai pembobotan dan juga jenis beasiswa yang diberikan. Dalam penelitian yang penulis lakukan jenis beasiswa tidak hanya beasiswa prestasi tetapi juga beasiswa kurang mampu. Subjek penelitian juga berbeda, di penelitian ini subjeknya adalah siswa. Sedangkan di penelitian penulis subjek yang digunakan adalah mahasiswa. Metode yang digunakan sama yaitu weighted product akan tetapi studi yang diambil berbeda.

\section{A. Bahan dan Alat Penelitian \\ 1) Bahan Penelitian}

\section{METODE PENELITIAN}

Bahan penelitian yang akan digunakan dalam penelitian ini meliputi data-data kriteria yang berkaitan dengam pemberian beasiswa-PPA dan Beasiswa BBM di Politeknik Harapan Bersama, yaitu:

a) Beasiswa PPA

- IPK mahasiswa, semakin tinggi IPK maka nilai yang diberikan semakin besar.

- Jumlah SKS yang telah ditempuh, semakin banyak SKS yang telah diambil maka nilai yang diberikan semakin tinggi.

- Prestsi mahasiswa baik dalam bidang ekstrakulikuler (penalaran, minat dan bakat) tingkat nasional maupun internasional. 
- Tingkat ekonomi, semakin rendah penghasilan orang tua maka semakin tinggi nilai yang diberikan.

\section{b) Beasiswa BBM}

- Tingkat ekonomi, semakin rendah penghasilan orang tua maka semakin tinggi nilai yang diberikan.

- Prestasi mahasiswa dalam bidang ekstrakulikuler (penalaran, minat dan bakat).

- IPK mahasiswa, semakin tinggi IPK maka nilai yang diberikan semakin besar.

- Jumlah SKS yang telah ditempuh, semakin banyak SKS yang telah diambil maka nilai yang diberikan semakin tinggi.

- Lokasi tempat tinggal mahasiswa, jika mahasiswa berasal dari daerah $3 \mathrm{~T}$ maka nilai yang diberikan semakin tinggi.

\section{2) Alat Penelitian}

Alat penelitian yang digunakan dalam penelitian ini berupa perangkat keras dan perangkat lunak komputer. Dalam penelitian ini perangkat keras yang digunakan adalah sebuah notebook, sedangkan perangkat lunak yang digunakan yaitu:

- Notepad++ digunakan untuk pengeditan dan penulisan script pada aplikasi

- MySQL digunakan sebagai database

- Xampp digunakan sebagai server local (localhost)

- Star UML digunakan untuk pembuatan pemodelan UML.

- CodeIgniter; bahasa pemrograman berbasis framework yang digunakan untuk membangun aplikasi web dinamis mnggunakan PHP.

\section{B. Kerangka Penelitian}

Kerangka penelitian penerapan metode weighted product dalam sistem pendukung keputusan penerima beasiswa di politekik harapan bersama dapat dilihat pada Gbr 1 .

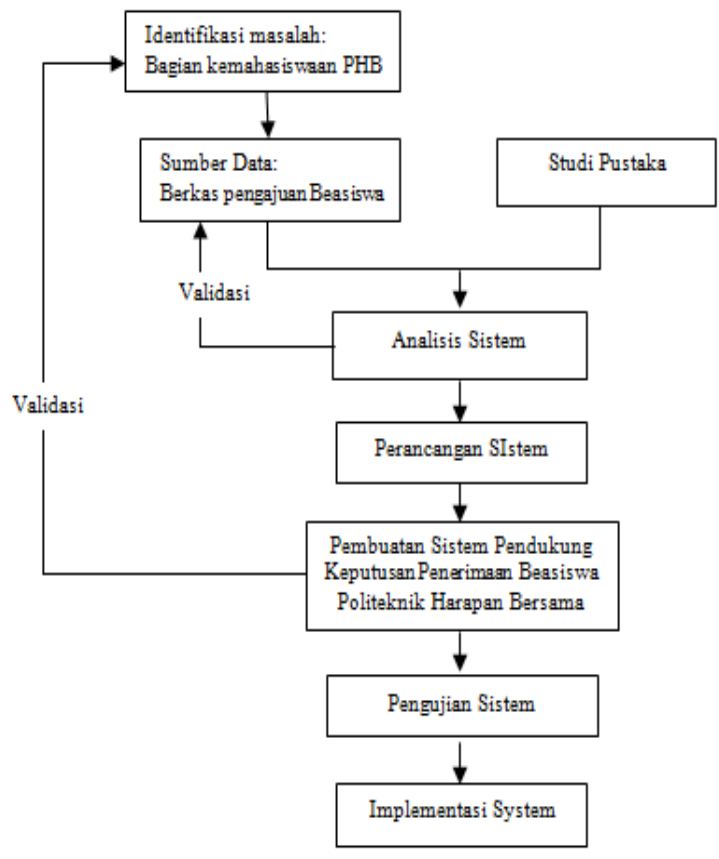

Gbr.1 Kerangka Penelitian
Kerangka penelitian yang ada dalam penelitian ini dimulai dengan proses identifikasi masalah yang didiskusikan dengan bagian kemahasiswaan PHB. Setelah diketahui permasalahannya tahapan selanjutnya adalah proses studi pustaka yang dilakukan dengan melihat berkas pengajuan beasiswa oleh mahasiswa dan juga pencarian referensi dengan studi pustaka. Analisis sistem dilakukan untuk mencari solusi dari permasalahan yang telah diidentifikasikan sebelumnya, dari analisa yang dihasilkan dilanjutkan dengan perancangan sistem dan juga pembuatan sistem pendukung keputusan penerimaan beasiswa. Sistem yang sudah dibuat selanjutnya diuji dengan menggunakan metode pengujian sistem. Setelah dilakukan uji coba sistem tahapan selanjutnya adalah implementasi/penerapan sistem yang telah dibuat.

\section{Metode Pengembangan Sistem}

Metode pengembangan sistem dalam penelitian ini menggunakan pendekatan System Development Live Cycle (SDLC) dengan metode Waterfall. Metode waterfall merupakan sebuah pendekatan yang digunakan untuk penegmbangan perangkat lunak, dimulai dengan analisis kebutuhan (requirement), desain sistem (design system), Implementasi sistem (implementation), integrasition \& maintenance dan operation \& maintenance. Adapun langkah dalam metode waterfall dapat dilihat pada Gbr 2.

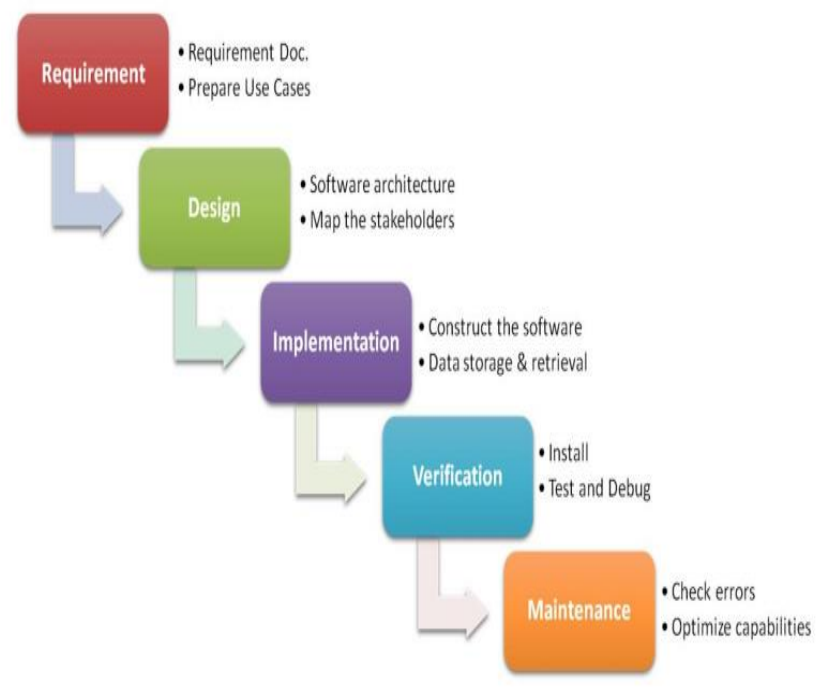

Gbr.2 Pengembangan Sistem Waterfall

Adapun fase-fase dalam metode Waterfall yaitu [12]:

a) Requirement Analysis and Definition: Tahap requirement Analysis and definition merupahan tlangkah awal yang dilakukan dalam metode waterfall. Pada tahap ini akan dilakukan identifikasi masalah, pengumpulan data yang berkaitan dengan penelitian dan analisa data.

b) System and Software Design: Pada tahapan ini akan dilakukan proses pembuatan desain sistem yang mau dibuat. Dalam tahapan ini akan dibuat perancangan sistem menggunakan UML dan Perancangan User Interface.

c) Implementation and Unit Testing: Proses implementasi ini merupakan proses pembuatan aplikasi dengan mengubah desain yang sudah dirancang ke dalam bentung kode program menggunakan framework CodeIgniter. Program yang sudah dibangun langsung diuji secara unit. 
d) Integration and system Testing: Setelah aplikasi dibuat tahapan selanjutnya adalah penyatuan unit unit program dan dilanjutkan dengan proses pengujian aplikasi. Pengujian dilakuakan untuk mengetahui apakah sistem yang dibuat dapat digunakan dan berfungsi dengan baik. Pengujian sistem dilakukan dengan menggunakan metode Black Box Testing dan usability Testing. Pengujian dengan Black Box Testing digunakan untuk menguji masing-masing fungsi yang ada dalam aplikasi apakan sudah sesuai atau masih ada kesalahan. Sedangkan usability testing digunakan untuk evaluasi produk dari pengguna aplikasinya.

e) Operation and Maintenance: Pengoperasian software dan juga pemeliharaan software sangatlah penting, termasuk didalamnya adalah pengembangan software.

\section{HASIL DAN PEMBAHASAN}

\section{A. Perancangan Sistem}

Pada proses perancanagn penerapan metode weight product dalam sistem pendukung keputusan penerima beasiswa dapat dilihat pada Gbr 3. Berdasarkan perancangan yang telah dibuat dapat diketahui bahwa sistem ini memiliki dua aktor yang akan menggunakan sistem ini yaitu user dan admin. Usecase yang ada dalam sistem ini yaitu login, melengkapi data pengajuan, riwayat pengajuan, pengumuman, logout, kelola data pengguna, kelola data program studi, kelola data mahasiswa, kelola data kriteria, seleksi dan laporan.

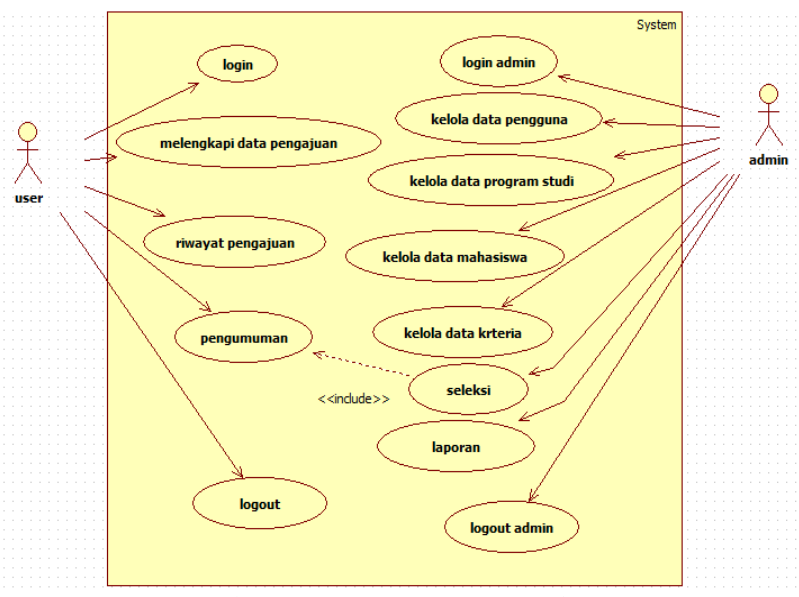

Gbr. 3 Perancangan Usecase Diagram

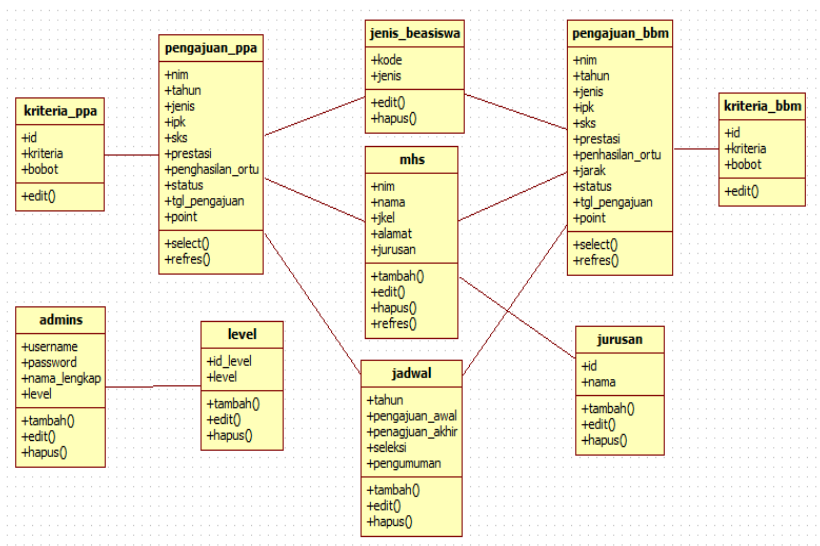

Gbr. 4 Class Diagram
Perancangan class diagram juga dilakukan dalam penelitian ini. Aplikasi ini memiliki beberapa class yang terdiri dari: admins, level, mhs, jadwal, jurusan, jenis beasiswa, kriteria_ppa, pengajuan_ppa, kriteria_bbm, pengajuan_bbm. Adapun perancangan class diagram ditunjukkan pada Gbr 4.

\section{B. Implementasi Sistem}

Sistem ini dibuat dengan menggunakan bahasa pemrograman PHP, dengan framework CodeIgniter. Implementasi database dalam sistem ini dibuat menggunakan MySQL dengan Xampp sebagai localhost-nya. Sistem pendukung keputusan penerima beasiswa ini memiliki beberapa menu. Adapun tampilan menu dari hasil penelitian ini dapat dilihat pada gambar-gambar berikut:

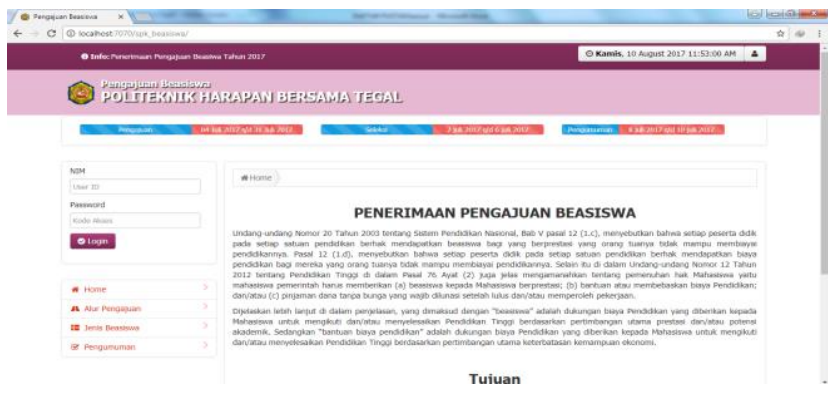

Gbr. 5 Tampilan Halaman Utama

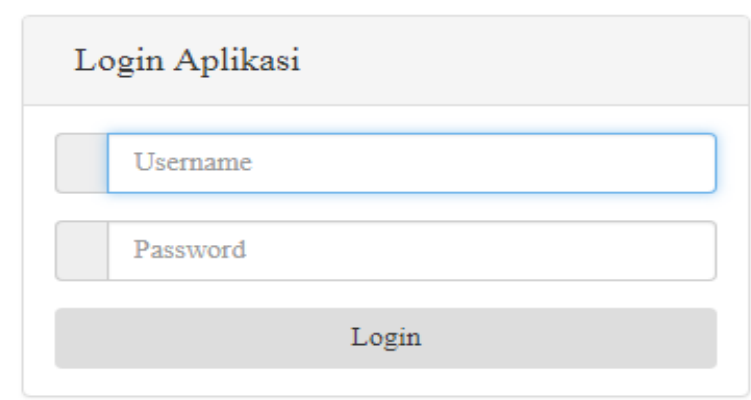

Gbr. 6 Tampilan Halaman Login

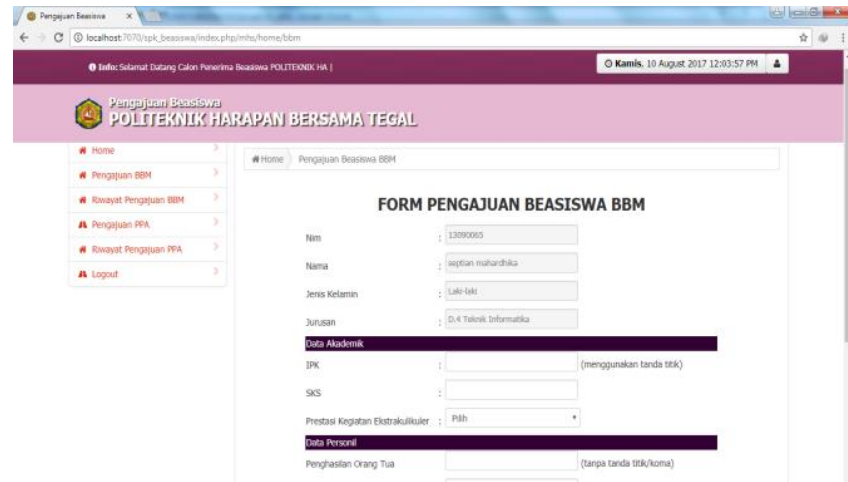

Gbr. 7 Tampilan Halaman Pengajuan

Gbr.5 merupakan Tampilan utama aplikasi ini. Pada halaman ini terdapat menu login untuk admin dan mahasiswa, 
menu menu lain seperti: menu home, alur pengajuan, jenis beasiswa, dan pengumuman. Pada Gbr. 6 dapat dilihat tampilan dari halaman login untuk aplikasi sistem pendukung keputusan pemberian beasiswa ini. Di halaman ini user yang terdiri dari admin dan mahasiswa dapat login dengan menggunakan username dan password yang sudah dimiliki oleh masing-masing user. Pada Gbr. 7 merupakan halaman pengajuan beasiswa. Halaman pengajuan ini akan tampil sesuai dengan jenis beasiswa yang ada dipilih. Beasiswa BBM maupun beasiswa PPA hampir memiliki tampilan yang sama, dikarenakan kriteria yang digunakan untuk kedua beasiswa tersebut hampir sama, yang membedakan hanyalah pembobotan yang digunakan.

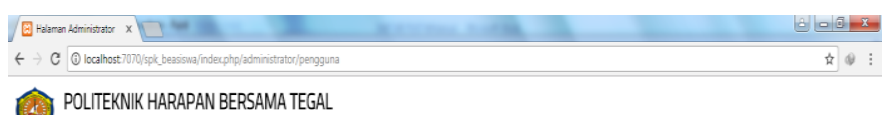
POLITEKNIK HARAPAN BERSAMA TEGAL

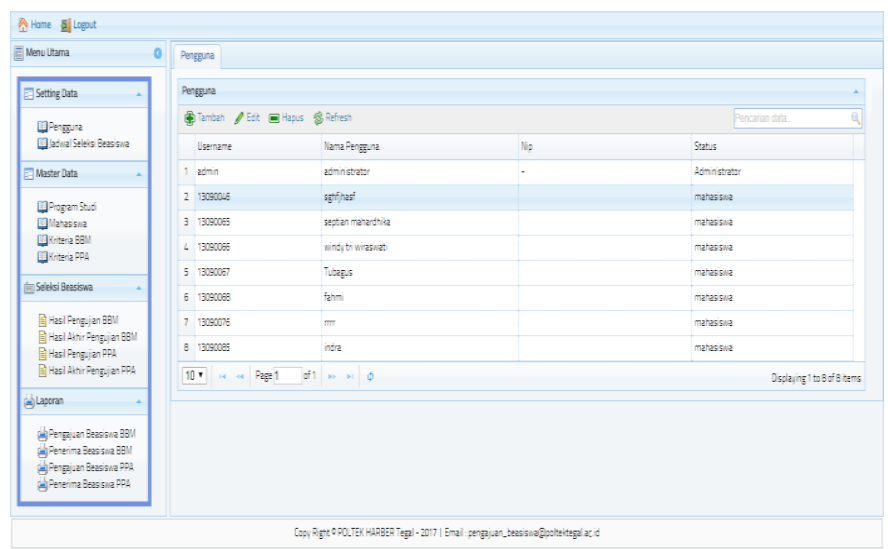

Gbr. 8 Tampilan Halaman Data Pengguna

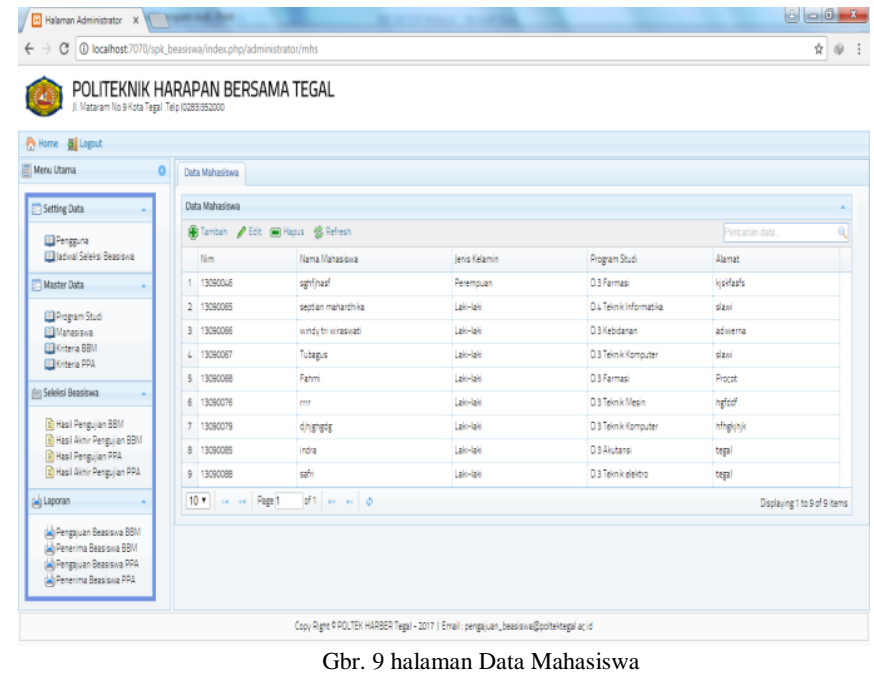

Pada Gbr. 8 merupakan tampilan untuk data pengguna. Pada hamalan ini admin dapat menambah, mengubah, menghapus dan menentukan user dan password untuk pengguna. Pada Gbr. 9 dapat dilihat tampilan data mahasiswa, pada halaman ini dapat dilihat informasi mahasiswa yang berupa nim, nama, jenis kelamin, program studi, dan alamat

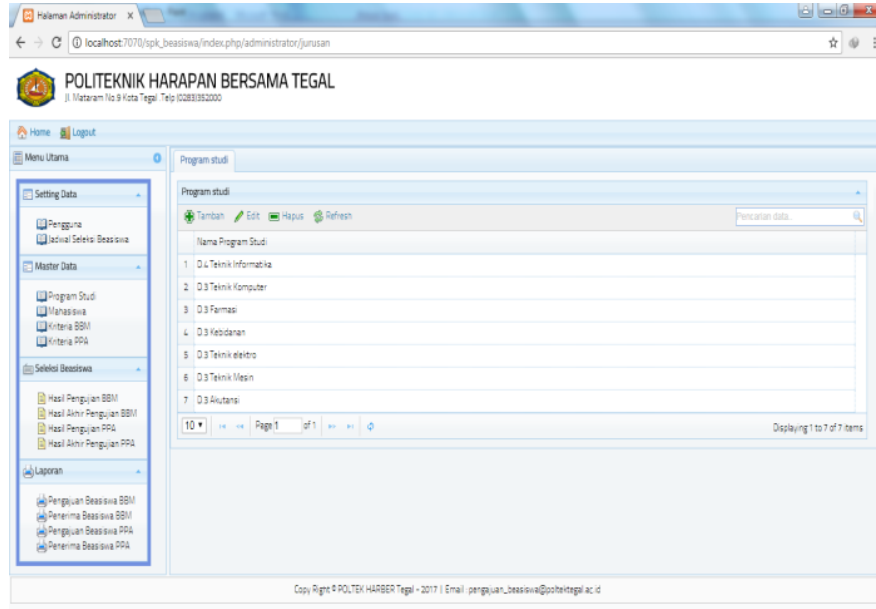

Gbr. 10 Tampilan Halaman Program Studi

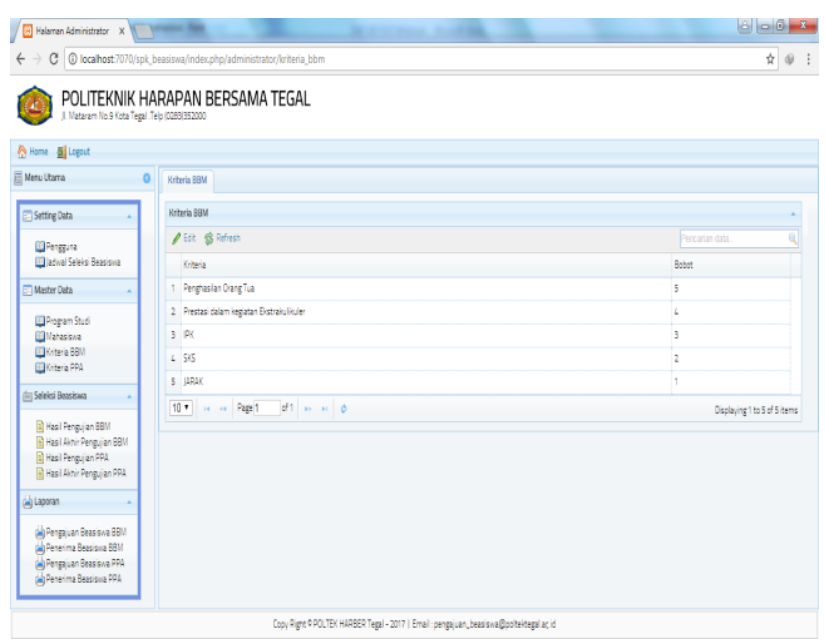

Gbr. 11 Tampilan Halaman Data Kriteria

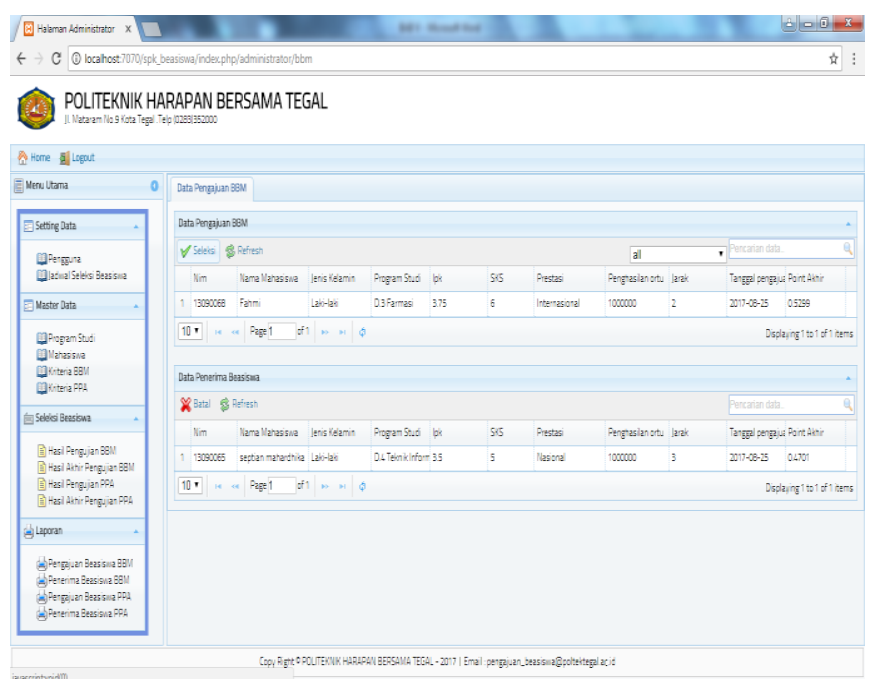

Gbr. 12 Tampilan Hasil Seleks

Pada Gbr. 10 dapat dilihat tampilan data program studi. Pada halaman ini admin dapat menambah, mengedit dan menghapus data program studi. Pada Gbr.11 ini dapat dilihat tampilan data kriteria. Halaman ini berisi halaman dapat dilakukan proses tambah, edit, hapus kriteria dan juga bobot 
dari masing-masing kriteria. Proses pembobotan yang diberikan dalam kriteria ini menyesuaikan kebutuhan dari pengambil keputusan. Semakin penting kriteria makan nilai bobotnya juga semakin besar. Kriteria yang digunakan dalam beasiswa BBM dan PPA hamper sama, yaitu IPK, Jumlah SKS, prestasi mahaissswa dan tingkat ekonomi, dan jarak tempuh, yang membedakankriteria dari kedua beasiswa tersebut adalah pada proses pembobotan yang diberikan.

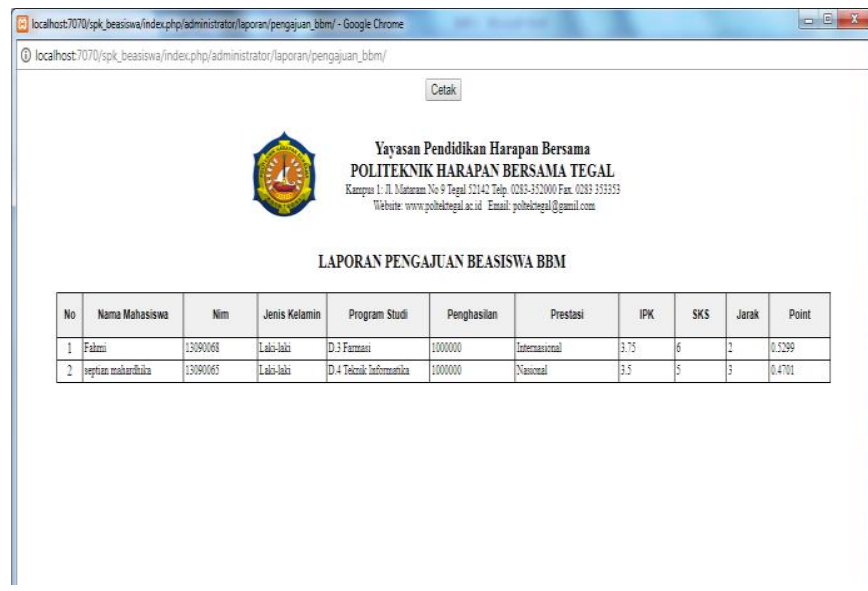

Gbr. 13 Tampilan Halaman Laporan

Pada Gbr. 12 dapat dilihat tampilan hasil seleksi. Proses hasil seleksi ini dilakukan setelah proses penentuan kriteria dan pembobotan dilakukan, tahapan selanjutnya yaitu dilakukan perhitungan terhadap alternatif sesuai dengan kriteria yang telah ditentukan menggunakan metode Weight Product. Nilai yang diinputkan oleh user (mahasiswa) selanjutnya di proses sesuai dengan pembobotan yang sudah ditentukan oleh pengambil keputusan. Pemberian bobot (W) dalam metode ini ditentukan oleh pengambil keputusan yang ditentukan berdasarkan tingkat kepentingan yaitu: sangat tidak penting dengan nilai bobot 1 , tidak penting dengan nilai bobot 2 , cukup penting dengan nilai bobot 3 , penting dengan nilai bobot 4 dan sangat penting dengan nilai bobot 5[13]. Bobot yang diinputkan selanjutnya dinormalisasi dengan menggunakan persamaan 1, seperti dibawah ini;

$$
W_{j}=\frac{W_{j}}{\sum W_{j}}
$$

Dimana:

$$
\begin{aligned}
& W_{j}=\text { bobot indeks ke } \mathrm{j} \\
& \Sigma W_{j}=\text { jumlah semua bobot }
\end{aligned}
$$

Tahapan selanjutnya setelah kita peroleh bobot yang telah dinormalisasi, tentukan nilai vektor (S), untuk menghasilkan nilai vektor (S) dilakukan dengan cara menghubungkan rating atribut dengan memangkapkan rating atributnya dengan bobot criteria yang sudah dinormalisasi. Persamaan untuk menghitung nilai vektor (S) dapat dilihat dalam persamaan 2:

$$
S i=\prod_{j=1}^{n} X_{i j j^{j j}} \text { dimana } i=1,2,3 \ldots . n
$$

Setelah ditemukan nilai vektor(S) tahapan selanjutnya adalah melakukan perhitungan terhadap nilai vektor (V) yang akan digunakan untuk perankingan. Perhitungan nilai vektor (V) dapat dilakukan dengan menggunakan persamaan 3:

$$
V i=\frac{\prod_{j=1}^{n} X_{i j} W j}{\prod_{j=1}^{n} X_{\left(j j^{j}\right)^{W j}}}, \text { dimana } i=1,2,3 \ldots n
$$

Nilai V dalam metode Weighted Product merupakan nilai preferensi yang menunjukkan perangkingan. Semakin besar nilai $\mathrm{V}$ dari sebuah alternative yang dihasilkan, berarti alternative tersebut merupakan alternative yang terbaik. Hasil akhir dari penelitian ini menghasilkan sebuah perangkingan dengan berdasarkan nila itertinggi dari vektor $\mathrm{V}$ yang diperoleh. Hasil perangkingan ditampilkan dalam menu hasil seleksi di dalam sistem. Pada Gbr.13 memperlihatkan admin memilih laporan pengajuan beasiswa yang ingin dicetak, kemudian pilih semua yang ditampilkan atau hanya slah satu prodi saja yang ingin dicetak.

\section{Pengujian Sistem}

Dalam penelitian ini digunakan dua metode pengujian sistem, yaitu:

\section{1) Pengujian Blackbox}

Pengujian Black box merupakan pengujian terhadap user interface apakah input/output yang ditampilkan oleh sistem sudah sesuai dengan yang diharapkan atau belum sesuai [14]. Jika sitem diberi masukan tertentu dan hasil keluaran sesuai dengan hasil yang diharapkan, maka sistem dapat dikatakan

\begin{tabular}{|c|c|c|c|c|}
\hline No & Uji Fungsional & Output yang diharapkan & Hasil & Kesimpulan \\
\hline 1 & Halaman Utama & $\begin{array}{l}\text { Sistem memunculkan } \\
\text { halaman utama }\end{array}$ & $\begin{array}{l}\text { Halaman utama } \\
\text { tampil }\end{array}$ & Berhasil \\
\hline 2 & Halaman login & $\begin{array}{l}\text { User dapat login } \\
\text { sehingga muncul menu } \\
\text { dashboard }\end{array}$ & $\begin{array}{l}\text { Menu dashboard } \\
\text { tampil }\end{array}$ & Berhasil \\
\hline 3 & Pengajuan Beasiswa & $\begin{array}{l}\text { Menampilkan halaman } \\
\text { pengajuan beasiswa }\end{array}$ & $\begin{array}{l}\text { Halaman } \\
\text { pengajuan } \\
\text { beasiswa tampil }\end{array}$ & Berhasil \\
\hline 4 & Data Pengguna & $\begin{array}{l}\text { Menampilkam data } \\
\text { pengguna }\end{array}$ & \begin{tabular}{|l}
$\begin{array}{l}\text { Data pengguna } \\
\text { tampil }\end{array}$ \\
\end{tabular} & Berhasil \\
\hline 5 & Data mahasiswa & $\begin{array}{l}\text { Menampilkan data } \\
\text { mahasiswa }\end{array}$ & $\begin{array}{l}\begin{array}{l}\text { Data mahasiswa } \\
\text { tampil }\end{array} \\
\end{array}$ & Berhasil \\
\hline 6 & Data Program studi & $\begin{array}{l}\text { Menampilkan data } \\
\text { program studi }\end{array}$ & $\begin{array}{l}\text { Data program studi } \\
\text { Tampil }\end{array}$ & Berhasil \\
\hline 7 & Data kriteria & $\begin{array}{l}\text { menampilkan data } \\
\text { kriteria }\end{array}$ & kriteria tampil & Berhasil \\
\hline 8 & Hasil seleksi & $\begin{array}{l}\text { menampilkan hasil } \\
\text { seleksi }\end{array}$ & $\begin{array}{l}\text { hasil seleksi dapat } \\
\text { tampil }\end{array}$ & Berhasil \\
\hline 9 & Data Laporan & $\begin{array}{l}\text { Menampilkan data } \\
\text { laporan }\end{array}$ & Dta laporan tampil & Berhasil \\
\hline
\end{tabular}
lolos pengujian Black box. Tabel 1 adalah hasil dari pengujian Black Box.

TABEL I

HASIL PENGUJiAn BLACK BoX

\section{2) Pengujian Usability}

Pengujian kegunaan (Usability Testing) yang dilakukan yaitu pengujian terhadap kepuasan user untuk mengetahui kualitas dari sitem yang dibuat. Alat ukur yag digunakan adalah kuisioner SUS (System Usability Scale). Berdasarkan pengujian SUS yang telah dilakukan ke responden diperoleh 
nilai rata-rata skor akhir SUS sebesar 73,75. Hasil tersebut selanjutnya diinterpretasikan mengggunakan kisaran rating penerimaan (acceptability), skala nilai (grade) dan adjective rating seperti yang ditunjukkan pada Gbr. 14 [15].

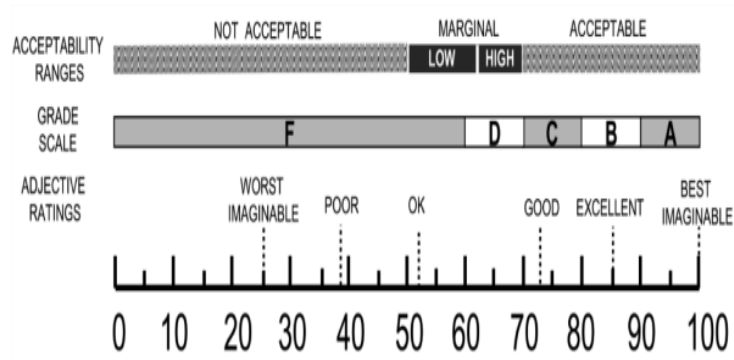

Gbr. 14 Rating dan Skala Skor SUS

Berdasarkan skor yang telah diperoleh yaitu sebesar 73,75 , berdasarkan acceptability range masuk ke dalam kategori acceptable, kemudian grade scale $\mathrm{C}$, dan adjective range mendapat nilai good. Dari hasil intepretasi nilai SUS menunjukkan bahwa aplikasi sistem pendukung keputusan penerimaan beasiswa yang telah dibuat dapat diterima.

\section{KESIMPULAN}

Berdasarkan hasil yang telah diperoleh dari penelitian penerapan Metode Weight Product dalam Sistem pendukung Keputusan Penerima Beasiswa di Politeknik Harapan Bersama dapat disimpulkan bahwa aplikasi sistem pendukung keputusan penerimaan beasiswa politeknik harapan bersama mampu melakukan proses perangkingan berdasarkan kriteria yang telah ditentukan, dan mampu menghasilkan laporan data penerima beasiswa dalam periode tahun tertentu. Aplikasi ini memiliki tingkat akseptabilitas yang tinggi sehingga bias diterima dan digunakan dengan baik oleh penggunanya dan siap untuk diimplementasikan.

Saran yang dapat diberikan dalam penelitian ini yaitu dengan adanya sistem ini diharapkan dapat digunakan dengan baik sesuai yang diharapkan, perlu dikembangkan lagi pada jenis beasiswa yang disediakan, dan sistem ini dapat diintegrasikan dengan sistem yang ada di Politeknik Harapan Bersama.

\section{UCAPAN TERIMA KASIH}

Pada kesempatan ini penulis ingin menyampaikan ucapan terima kasih penulis kepada pihak yang membantu dan memberikan dukungan terhadap penelitian ini, kepada Politeknik Harapan Bersama Tegal sebagai tempat penelitian.
DAFTAR PUSTAKA

[1] N. Nurjannah, Z. Arifin, and D. M. Khairina, "Sistem Pendukung Keputusan Pembelian Sepeda Motor Dengan Metode Weighted Product," J. Inform. Mulawarman, vol. 10, no. 2, pp. 2-6, 2015.

[2] M. Behzadian, R. B. Kazemzadeh, A. Albadvi, and M. Aghdasi, "PROMETHEE: A comprehensive literature review on methodologies and applications," Eur. J. Oper. Res., vol. 200, no. 1, pp. 198-215, 2010.

[3] D. Apriliani, K. Adi, and R. Gernowo, "Implementasi Metode Promethee dan Borda Dalam Sistem Pendukung Keputusan Pemilihan Lokasi Pembukaan,” J. Sist. Inf. Bisnis, vol. 5, no. 2, pp. 145-150, 2015 .

[4] W. Supriyanti, "Rancang Bangun Aplikasi Sistem Pendukung Keputusan Penerima Beasiswa dengan Metode SAW," vol. 1, no. 1, pp. 67-75, 2014.

[5] Kusumadewi S, "Pencarian Bobot Atribut pada Multiple Attribute Decision Making (MADM) dengan Pendekatan Objektif Menggunakan Algoritma Genetika (Studi Kasus: Rekrutmen Dosen Jurusan Teknik Informatika Universitas Islam Indonesia)," $J$. Gematika Manaj. Inform., vol. 7, no. 1, pp. 48-56.

[6] A. Setyawan, F. Y. Arini, and I. Akhlis, "Comparative Analysis of Simple Additive Weighting Method and Weighted Product Method to New Employee Recruitment Decision Support System ( DSS ) at PT . Warta Media Nusantara," Sci. J. Informatics, vol. 4, no. 1, pp. 34-42, 2017.

[7] M. Wang, S. Liu, S. Wang, and K. K. Lai, "A weighted product method for bidding strategies in multi-attribute auctions," J. Syst. Sci. Complex., vol. 23, no. 1, pp. 194-208, 2010.

[8] V. G. S. and M. C. S., "Comparative Study of Different Multi-criteria Decision-making Methods," Int. J. Adv. Comput. Theory Eng., vol. 2 no. 4, pp. 9-12, 2013.

[9] E. Suryeni, Y. H. Agustin, and Y. Nurfitria, "Sistem Pendukung Keputusan Kelayakan Penerimaan Bantuan Beras Miskin Dengan Metode Weighted Product Di Kelurahan Karikil Kecamatan Mangkubumi Kota Tasikmalaya," Konf. Nas. Sist. Inform., no. sistem pendukung keputusan, pp. 345-350, 2015

[10] A. Ahmadi and D. T. Wiyanti, "Implementasi Weighted Product (WP) dalam Penentuan Penerima Bantuan Langsung Masyarakat PNPM Mandiri Perdesaan,” Semin. Nas. Apl. Teknol. Inf., pp. 19-22, 2014.

[11] Basri, "Metode Weightd Product (Wp) Dalam Sistem Pendukung Keputusan Penerimaan Beasiswa Prestasi," J. INSYPRO (Information Syst. Process., vol. 2, no. 1, pp. 1-6, 2017.

[12] R. S. Pressman, Rekayasa Perangkat Lunak. Yogyakarta: Penerbit Andi, 2010

[13] D. M. Khairina, D. Ivando, and S. Maharani, "Implementasi Metode Weighted Product Untuk Aplikasi Pemilihan Smartphone Android," $J$. Infotel, vol. 8, no. 1, pp. 1-8, 2016.

[14] A. Rouf, "Pengujian Perangkat Lunak Dengan Menggunakan Metode White Box dan Black Box," J. Teknol. Inf. HIMSYA-Tech, vol. 8, no. 1, pp. 1-7, 2012.

[15] A. Bangor, P. Kortum, and J. Miller, "Determining what individual SUS scores mean: Adding an adjective rating scale," J. usability Stud., vol. 4, no. 3, pp. 114-123, 2009. 